\title{
Prediksi Kelulusan Mata Kuliah Menggunakan Hybrid Fuzzy Inference System
}

\author{
Abidatul Izzah ${ }^{1}$ dan Ratna Widyastuti ${ }^{2}$ \\ ${ }^{1,2}$ Teknik Informatika Politeknik Kediri, Kediri \\ E-mail: ${ }^{1}$ abidatul.izzah90@ gmail.com, ${ }^{2}$ nana89widya@gmail.com
}

\begin{abstract}
Abstrak
Perguruan Tinggi merupakan salah satu institusi yang menyimpan data yang sangat informatif jika diolah secara baik. Prediksi kelulusan mahasiswa merupakan kasus di Perguruan Tinggi yang cukup banyak diteliti. Dengan mengetahui prediksi status kelulusan mahasiswa di tengah semester, dosen dapat mengantisipasi atau memberi perhatian khusus pada siswa yang diprediksi tidak lulus. Metode yang digunakan sangat bervariatif termasuk metode Fuzzy Inference System (FIS). Namun dalam implementasinya, proses pembangkitan rule fuzzy sering dilakukan secara random atau berdasarkan pemahaman pakar sehingga tidak merepresentasikan sebaran data. Oleh karena itu, dalam penelitian ini digunakan teknik Decision Tree (DT) untuk membangkitkan rule. Dari uraian tersebut, penelitian bertujuan untuk memprediksi kelulusan mata kuliah menggunakan hybrid FIS dan DT. Data yang digunakan dalam penelitian ini adalah data nilai Posttest, Tugas, Kuis, dan UTS dari 106 mahasiswa Politeknik Kediri pengikut mata kuliah Algoritma dan Struktur Data. Penelitian ini diawali dari membangkitkan 5 rule yang selanjutnya digunakan dalam inferensi. Tahap selanjutnya adalah implementasi FIS dengan tahapan fuzzifikasi, inferensi, dan defuzzifikasi. Hasil yang diperoleh adalah akurasi, sensitivitas, dan spesifisitas masing-masing adalah $94.33 \%, 96.55 \%$, dan $84.21 \%$.
\end{abstract}

Kata kunci: Decision Tree, Educational Data Mining, Fuzzy Inference System, Prediksi.

\begin{abstract}
College is an institution that holds very informative data if it mined properly. Prediction about student's graduation is a common case that many discussed. Having the predictions of student's graduation in the middle semester, lecturer will anticipate or give some special attention to students who would be not passed. The method used to prediction is very varied including Fuzzy Inference System (FIS). However, fuzzy rule process is often generated randomly or based on knowledge experts that not represent the data distribution. Therefore, in this study, we used a Decision Tree (DT) technique for generate the rules. So, the research aims to predict courses graduation using hybrid FIS and DT. Dataset used is the posttest score, tasks score, quizzes score, and middle test score from 106 students of the Polytechnic Kediri who took Algorithms and Data Structures. The research started by generating 5 rules by decision tree. The next is implementation of FIS that consist of fuzzification, inference, and defuzzification. The results show that the classifier give a good result in an accuracy, sensitivity, and specificity respectively was $94.33 \%, 96.55 \%$ and $84.21 \%$.
\end{abstract}

Keywords: Decision Tree, Educational Data Mining, Fuzzy Inference System, Prediction.

\section{Pendahuluan}

Saat ini penerapan data mining sangat berkembang pesat. Ketersediaan data dalam jumlah besar menjadi salah satu faktor utama. Dunia kampus merupakan salah satu institusi yang menyimpan data informatif jika diolah secara baik. Penggalian informasi data di dunia pendidikan sering disebut dengan Educational Data Mining (EDM). EDM dapat digunakan dalam pengolahan data seperti penentuan lama masa studi (Lindawati, 2008), prediksi kemampuan menangkap materi (Yadav dan Pal, 2012), prediksi mata kuliah yang diambil (Virgiawan dan Mukhlash, 2013), penentuan minat kerja (Swanjaya dan Izzah, 2015), dan penentu penerima beasiswa (Khan dan Choi, 2014). Salah satu penerapan EDM untuk prediksi kelulusan merupakan bagian penting dalam perkuliahan. Dengan prediksi mengetahui kelulusan akhir perkuliahan di tengah semester, maka dosen akan mampu memberikan perhatian khusus pada mahasiswa yang diprediksi tidak lulus.

Pada beberapa penelitian sebelumnya, teknik data mining dalam bidang klasifikasi seperti KNN (Mentari, Sari, dan Dewi, 2016) (Mutrofin, Izzah, Kurniawardhani, dan Masrur, 2014) Fuzzy Inference System (FIS), k-means, dan Decision Tree (DT) digunakan sebagai metode dalam pengolahan data.

60 | Register: Jurnal Ilmiah Teknologi Sistem Informasi, Juli 2016, Volume 2, Nomor 2 
Metode fuzzy sudah sering digunakan dalam kasus klasifikasi dan memberikan hasil yang bagus dalam klasifikasi maupun prediksi. Fuzzy memiliki keunggulan dalam hal perhitungannya yang tidak kaku (samar), sehingga mampu memperhitungkan kemungkinan tidak pasti (Urbanowicz dan Moore, 2009). Namun dalam hal ini, fuzzy memiliki kerumitan dalam hal penentuan rule atau aturan-aturan basis yang digunakan saat inferensi. Beberapa kasus fuzzy menggunakan rule yang diperoleh secara random. Hal ini dikhawatirkan tidak mencerminkan representasi data sesungguhnya. Dari permasalahan tersebut, maka diperlukan sebuah metode khusus untuk penentuan rule dari FIS. Oleh karena itu pada penelitian ini, rule prediksi kelulusan dari FIS akan dibangkitkan menggunakan DT. Dengan demikian rule yang digunakan dalam mesin inferensi akan merepresentasikan keadaan yang sebenarnya. Dari uraian tersebut, penelitian ini bertujuan untuk memprediksi kelulusan mata kuliah sebagai alat bantu dosen dan mahasiswa untuk mengevaluasi proses pembelajaran dalam tengah semester. Prediksi dilakukan menggunakan metode hybrid FIS dan DT.

\section{Metode Penelitian}

Prosedur yang digunakan dalam penelitian ini dimulai dari pengambilan data nilai mahasiswa. Selanjutnya dari data tersebut dilakukan pembangkitan rule menggunakan DT. Jumlah rule yang terbentuk tergantung pada hasil pembangkitan DT. Dari rule tersebut, data record setiap mahasiswa diklasifikasikan menjadi dua kelas yaitu lulus dan tidak lulus. Desain metode penelitian yang akan diterapkan dapat dilihat pada bagan Gambar 1.

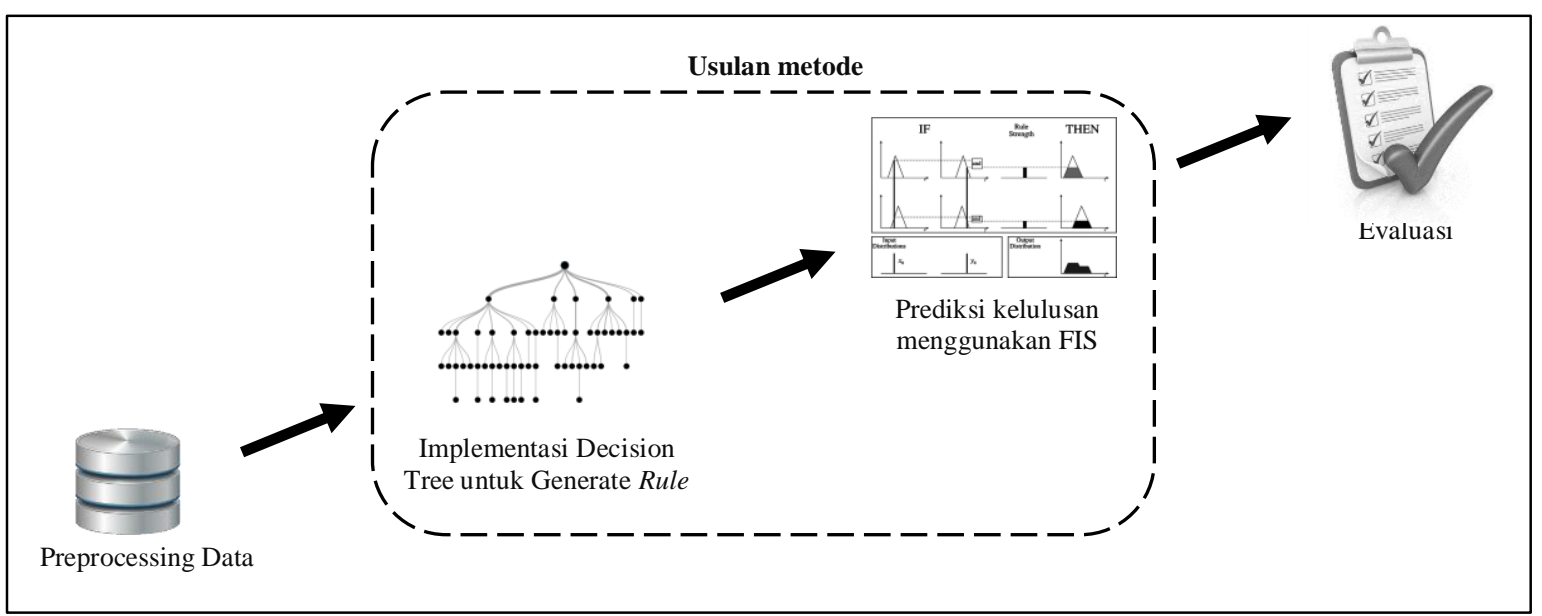

Gambar 1 Metode Penelitian

\subsection{Data Penelitian}

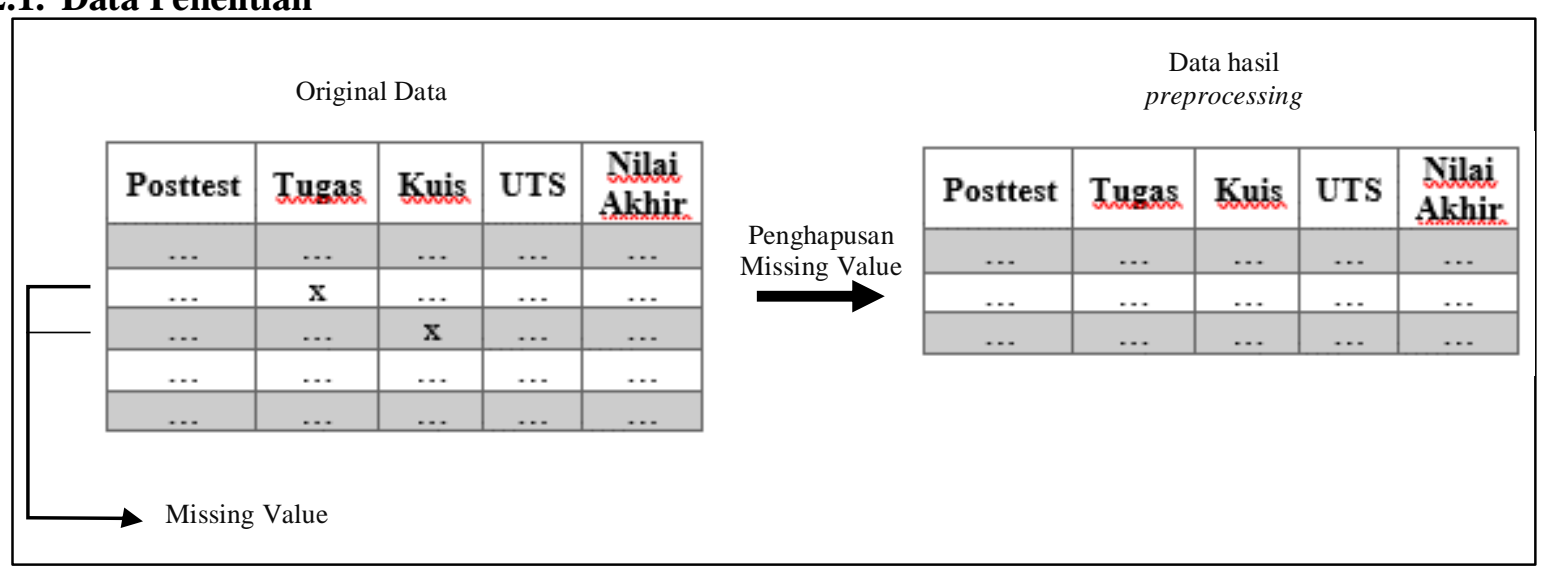

Gambar 2 Data Penelitian

Penelitian ini menggunakan data dari nilai akhir mata kuliah Algoritma dan Struktur Data tahun ajaran 2015/2016 yang diambil dari mahasiswa Teknik Informatika Politeknik Kediri. Data sebanyak 106 record dari mahasiswa tersebut terdiri dari 4 fitur yakni nilai Posttest, Tugas, Kuis, dan nilai UTS pada tengah semester; dan satu label yakni nilai akhir kelulusan pada akhir semester. Nilai akhir 
kelulusan digunakan sebagai keputusan lulus dan tidak lulus. Preprocessing data dilakukan dengan cara penghapusan missing value. Missing value disebabkan oleh beberapa mahasiswa yang tidak mengikuti atau mengerjakan tes sehingga menyebabkan nilai kosong. Contoh data hasil preprocessing dalam penelitian ini dapat dilihat pada Gambar 2.

\subsection{Decision Tree sebagai Pembangkit Rule}

Pembangkitan rule dilakukan menggunakan teknik Decision Tree (DT). Dalam DT, model direpresentasikan sebagai sebuah pohon yang terdiri dari node. Setiap node merepresentasikan fitur, setiap percabangan merepresentasikan nilai, dan setiap daun merepresentasikan keputusan (Gorunescu, 2011). DT merupakan pendekatan divide-and-conquer yakni membagi-bagi permasalahan dengan konsep klasifikasi kemudian menyelesaikannya. Metode ini diruntut dari atas ke bawah dengan membagi fitur ke dalam beberapa kelas. Pembagian bertahap ini diproses secara rekursif sehingga dihasilkan fitur terakhir yang dapat menentukan kelas. Prosedur ini kemudian menghasilkan sebuah pohon yang dapat membangkitkan beberapa rule (Witten, Frank, dan Hall, 2011). Pada decision tree terdapat 3 jenis node, yaitu Root, Node Internal, dan leaf. Root merupakan node paling atas. Node ini tidak terdapat input di atasnya sehingga mungkin bisa tidak terdapat atau bisa mempunyai output lebih dari satu. Selanjutnya internal node yakni node percabangan. Pada node ini hanya terdapat satu input dan mempunyai output minimal dua. Dalam kasus ini root dan node internal berupa mata kuliah. Sedangkan leaf yang merupakan node akhir. Pada node ini hanya terdapat satu input dan tidak mempunyai output. Dalam kasus ini leaf adalah nilai kelulusan (Gorunescu, 2011).

Model dibangun dengan Decision Tree menggunakan Algoritma C4.5. Tahap ini diawali dengan menghitung nilai entropy yang akan digunakan untuk menghitung nilai gain masing-masing fitur. Fitur dengan nilai gain yang tertinggi, selanjutnya akan ditetapkan menjadi root. Rumus menghitung entropy dan gain ditunjukkan dalam Persamaan (1) dan Persamaan (2). Langkah perhitungan entropy dan gain pada tiap fitur ini diulang secara terus menerus hingga semua mata kuliah terpartisi. Proses dari Decision Tree ini akan berhenti jika semua mata kuliah dalam $\operatorname{simpul} N$ sudah mendapat kategori pekerjaan, tidak ada fitur mata kuliah di dalam record yang dipartisi lagi, dan tidak ada record di dalam cabang yang kosong (Gorunescu, 2011).

$$
\begin{aligned}
& \operatorname{Entropy}(S)=\sum_{n=1}^{c}-p_{i}{ }^{2} \log p_{i} \\
& \operatorname{Gain}(S, A)=\operatorname{Entropy}(S)-\sum_{v \in \operatorname{Values}(A)} \frac{\left|S_{v}\right|}{S} \operatorname{Entropy}\left(S_{v}\right)
\end{aligned}
$$

\subsection{Fuzzy Inference System}

Metode FIS adalah metode yang sering digunakan untuk klasifikasi. FIS yang digunakan pada penelitian ini adalah metode Fuzzy Sugeno. Dengan metode ini akan didapatkan besarnya prosentase kemiripan data dengan kelas yang tersedia. Pada proses pelabelan dengan metode Fuzzy Sugeno terdapat beberapa proses utama, yaitu fuzzifikasi, inferensi, dan defuzzifikasi. Pada fuzzifikasi, dibentuk sebuah himpunan fuzzy dan fungsi keanggotaan dari himpunan tersebut (Jang, Sun, dan Mizutani, 1997). Salah satu contoh fungsi keanggotaan dalam FIS dapat dilihat pada Gambar 3.

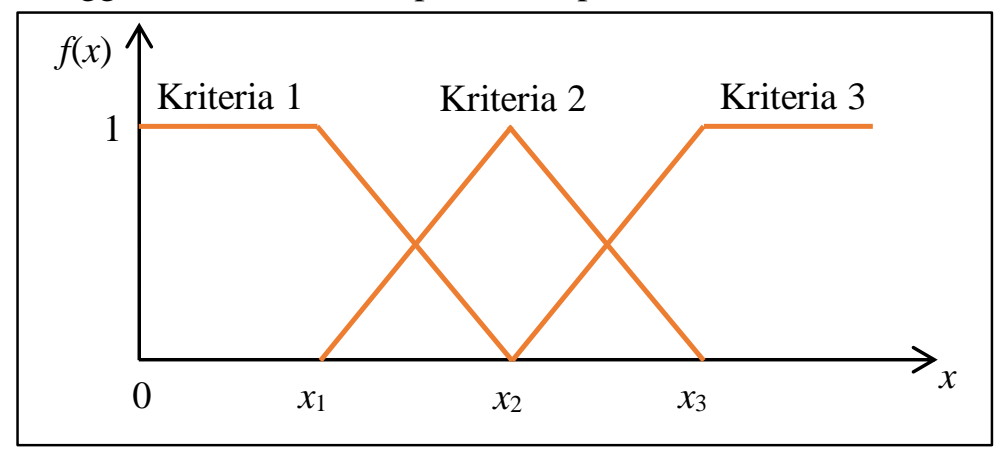

Gambar 3 Contoh kurva keanggotaan dalam fuzzy 
Jika $x$ adalah nilai masukan berupa nilai tes dengan interval $[0,100]$ dan $f(x)$ adalah nilai keanggotaan, maka fungsi keanggotaan untuk kriteria 1 dari Gambar 3 tersebut secara matematis dapat ditulis sebagai Persamaan (3).

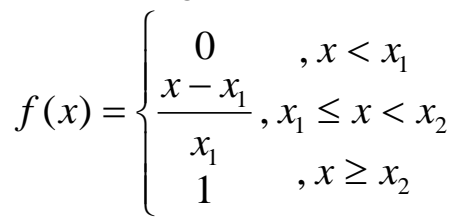

Tahap selanjutnya adalah inferensi fuzzy untuk menghasilkan output berupa rule. Berikut ini contoh beberapa rule yang akan digunakan dalam inferensi:

$$
\begin{aligned}
& \text { IF } \mathrm{x}_{1}={ }^{\prime} \text { Kriteria 1' AND } \mathrm{x}_{2}=\text { 'Kriteria 2' THEN } \mathrm{z}=\text { 'Kelas 1' } \\
& \text { IF } \mathrm{x}_{1}=\text { 'Kriteria 1' AND } \mathrm{x}_{3}=\text { 'Kriteria 3' THEN } \mathrm{z}=\text { 'Kelas 2' }
\end{aligned}
$$

Tahap terakhir adalah proses defuzzifikasi yang mengubah derajat nilai keanggotaan menjadi nilai yang sebenarnya. Pada tahapan ini akan didapatkan output akhir prosentase kemiripan fitur dengan kelas lulus atau tidak.

\section{Hasil Penelitian dan Pembahasan}

Sebuah DT dibentuk dari 106 record dengan 4 fitur berupa nilai Posttest, Tugas, Kuis, dan UTS dari mata kuliah Algoritma dan Struktur Data. Gambar 4 menunjukkan tree yang dibangkitkan dari dataset tersebut. Pada tree tersebut, nilai dari UTS terpilih sebagai root yang artinya nilai tersebut adalah nilai yang paling menentukan tingkat kelulusan. Percabangan nilai UTS dibatasi oleh nilai baik dan buruk, di mana nilai baik adalah nilai lulus dengan batas nilai C. Sedangkan nilai C akan diperoleh jika nilai tes mahasiswa mencapai angka $>50$. Jadi, jika seorang mahasiswa memperoleh nilai nilai UTS $>50$, maka besar kemungkinan dia akan lulus dalam mata kuliah tersebut. Selanjutnya, untuk leaf kedua terpilih Posttest dan Kuis. Lebih lanjut, nilai yang menentukan kemudian adalah nilai tugas. Lebih lanjut, tree hasil pembangkitan dapat dilihat pada Gambar 4.

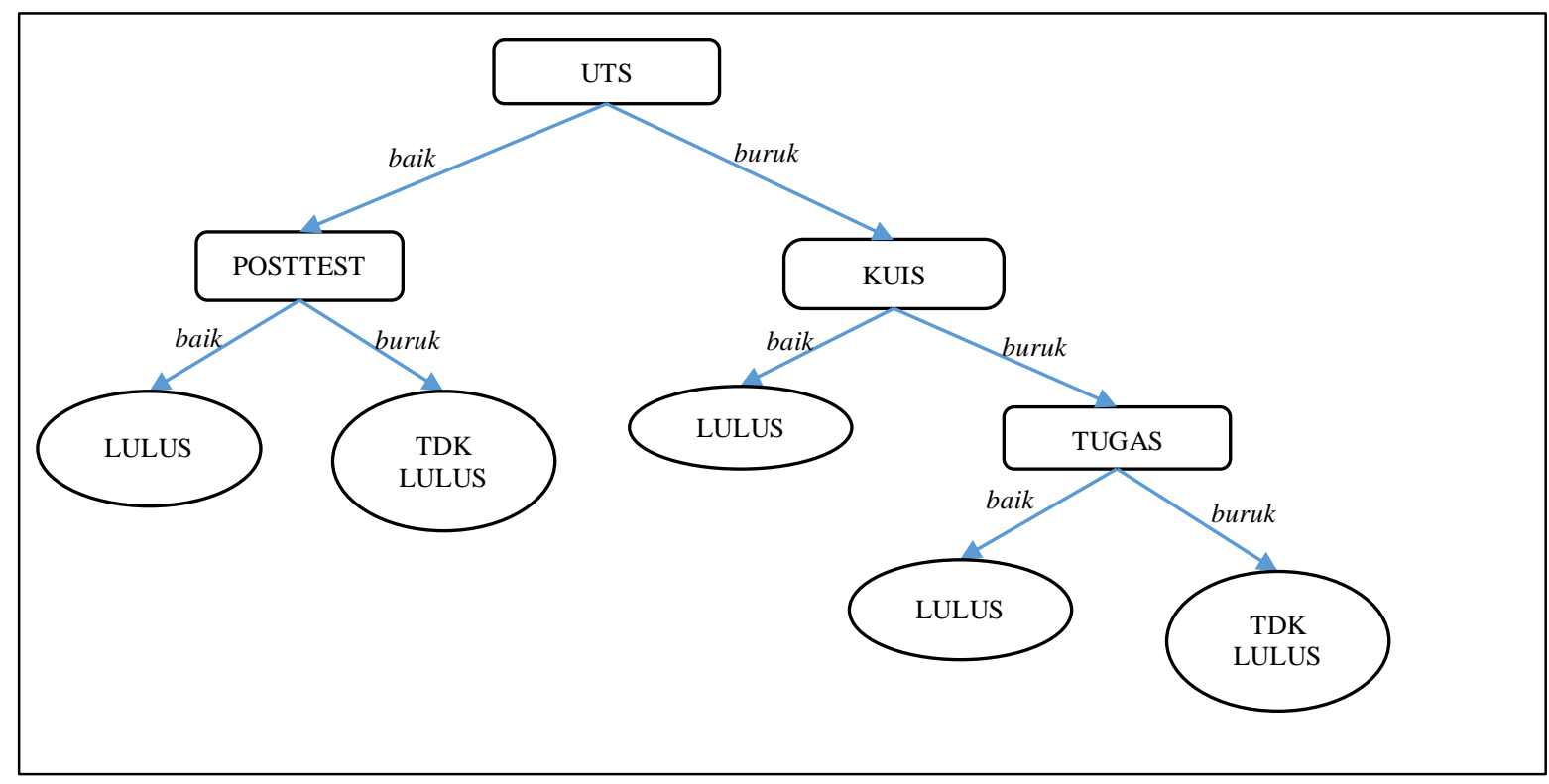

Gambar 4 Decision Tree yang dibangkitkan

Dari tree tersebut, terbentuklah lima rule sebagai berikut:

R1: IF UTS $=$ BAIK AND POSTTEST $=$ BAIK THEN STATUS $=$ LULUS

R2: IF UTS $=$ BAIK AND POSTTEST $=$ BURUK THEN STATUS $=$ TIDAK LULUS

R3: IF UTS $=$ BURUK AND KUIS $=$ BAIK THEN STATUS $=$ LULUS 
Selanjutnya dalam proses inferensi, kurva keanggotaan untuk variabel Posttest, Tugas, Kuis, dan UTS, didasarkan pada distribusi nilai yang ada di kelas tersebut. Kurva keanggotaan tersebut dapat dilihat pada Gambar 5.

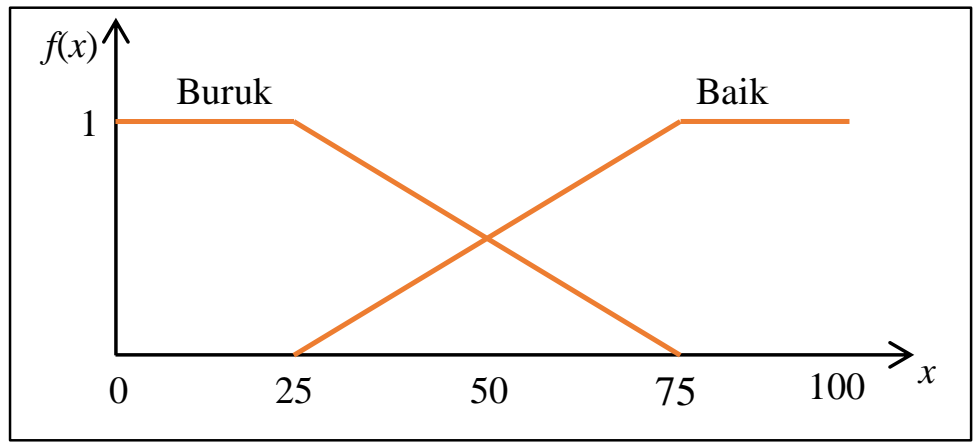

Gambar 5 kurva keanggotaan untuk variabel fitur

Berdasarkan kurva keanggotaan pada Gambar 5, maka fungsi keanggotaan untuk fitur yang berkategori buruk dan baik secara matematis masing-masing dapat ditulis seperti pada Persamaan (4) dan Persamaan (5).

$$
\begin{aligned}
& f(x)=\left\{\begin{array}{cc}
1 & , x<25 \\
\frac{x+25}{50} & , 25 \leq x<75 \\
0 & , x \geq 75
\end{array}\right. \\
& f(x)=\left\{\begin{array}{cc}
0 & , x<25 \\
\frac{x-25}{50} & , 25 \leq x<75 \\
1 & , x \geq 75
\end{array}\right.
\end{aligned}
$$

Selanjutnya dalam membangkitkan kurva keanggotaan untuk variabel kelulusan, didasarkan pada ketentuan nilai di kampus Politeknik Kediri. Nilai tes yang kurang dari 50 akan berbobot D dan berarti tidak lulus dalam mata kuliah tersebut. Oleh karena itu ambang batas dari kategori lulus dan tidak lulus adalah pada skor 50. Lebih lanjut kurva keanggotaan untuk variabel kelulusan dapat dilihat pada Gambar 6.

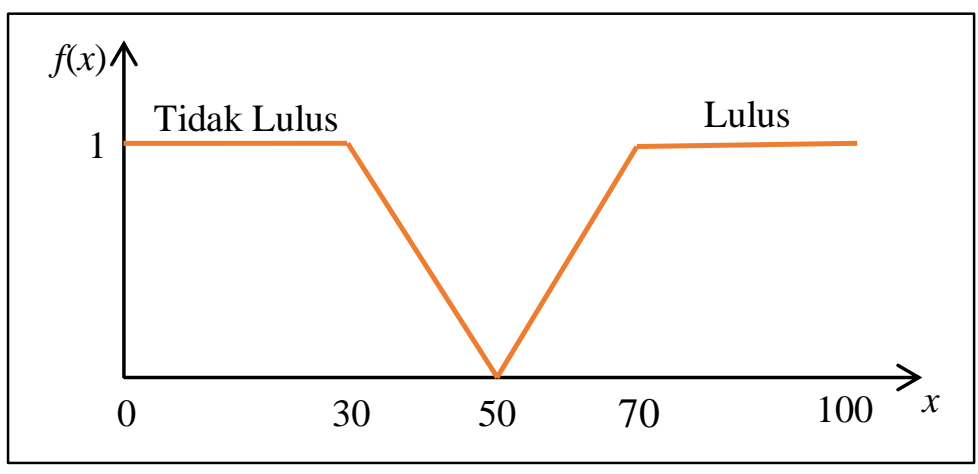

Gambar 6 Kurva keanggotaan untuk label

Berdasarkan kurva keanggotaan pada Gambar 6, maka fungsi keanggotaan untuk label yang berkategori tidak lulus dan lulus secara matematis masing-masing dapat ditulis seperti pada Persamaan (6) dan Persamaan (7). 


$$
\begin{aligned}
& f(x)=\left\{\begin{array}{cc}
1 & , x<30 \\
\frac{x+30}{20} & , 30 \leq x<50 \\
0 & , x \geq 50
\end{array}\right. \\
& f(x)=\left\{\begin{array}{cc}
1 & , x<50 \\
\frac{x-50}{20} & , 50 \leq x<70 \\
0 & , x \geq 75
\end{array}\right.
\end{aligned}
$$

Dari hasil klasifikasi 106 nilai mahasiswa tersebut akan dibandingkan dengan hasil nilai yang diperoleh dari pakar. Dari perbandingan tersebut akan diperhitungkan jumlah data yang True Positive (TP), True Negative (TN), False Positive (FP), dan False Negative (FN). TP dihitung dari jumlah mahasiswa lulus yang terklasifikasi lulus dan FN dihitung dari jumlah mahasiswa lulus yang terklasifikasi tidak lulus. Sedangkan FP dihitung dari jumlah mahasiswa tidak lulus yang terklasifikasi lulus dan TN dihitung dari jumlah mahasiswa tidak lulus yang terklasifikasi tidak lulus. Dari hasil tersebut maka diperoleh hasil seperti pada Tabel 1.

Tabel 1 Hasil Prediksi Kelulusan menggunakan Hybrid DT dan FIS

\begin{tabular}{lccc}
\hline & \multicolumn{2}{c}{ Hasil Prediksi } & \multirow{2}{*}{ Jumlah } \\
\cline { 2 - 3 } & Lulus & Tidak Lulus & \\
\hline Lulus & 84 & 3 & 87 \\
Tidak Lulus & 3 & 16 & 19 \\
\hline Jumlah & 87 & 19 & 106 \\
\hline
\end{tabular}

Beberapa kesalahan kategori FN dan FP dapat terjadi pada beberapa kasus seperti pada Tabel 2. Kesalahan prediksi FN yang terjadi mayoritas karena nilai Posttest yang buruk sehingga menyebabkan pembobotan antiseden pada rule ke-3 dan ke-4 bernilai rendah sedangkan pembobotan pada rule ke-2 bernilai tinggi. Hal ini menyebabkan data akan lebih terbobot ke kelas tidak lulus sesuai dengan konklusi pada rule ke-2. Sebaliknya kesalahan FP umumnya terjadi karena nilai Posttest yang baik mengakibatkan bobot rule ke-1 yang tinggi walaupun nilai UTS yang diperoleh di ambang batas kelulusan. Lebih lanjut, contoh beberapa kesalahan prediksi dapat dilihat pada Tabel 2.

Tabel 2 Contoh 4 Kesalahan Prediksi

\begin{tabular}{cccccc}
\hline Posttest & Tugas & Kuis & UTS & Hasil Prediksi & Hasil Pakar \\
\hline 61 & 30 & 50 & 75 & Tidak Lulus & Lulus \\
67 & 30 & 60 & 90 & Tidak Lulus & Lulus \\
82 & 20 & 40 & 50 & Lulus & Tidak Lulus \\
73 & 40 & 40 & 50 & Lulus & Tidak Lulus \\
\hline
\end{tabular}

Dari hasil klasifikasi tersebut kemudian dihitung akurasi, sensitivitas, dan spesifitas untuk mengukur kesuksesan classifier yang digunakan. Sensitivitas adalah proporsi data positif yang teridentifikasi dengan benar, sedangkan spesifisitas adalah proporsi data negatif yang teridentifikasi salah sebagai positif (Fawcett, 2006). Akurasi, sensitifitas, dan spesifitas dihitung menggunakan Persamaan (8), Persamaan (9), dan Persamaan (10).

$$
\begin{aligned}
& \text { Akurasi }=\frac{T P+T N}{T P+F P+T N+F N}=\frac{84+16}{84+3+19+3}=94.33 \% \\
& \text { Sensitivitas }=\frac{T P}{T P+F N}=\frac{84}{84+3}=96.55 \% \\
& \text { Spesifisitas }=\frac{T N}{T N+F P}=\frac{16}{16+3}=84.21 \%
\end{aligned}
$$


Akurasi sebesar 94.33\% menunjukkan bahwa prediksi kelulusan menunjukkan hasil yang bagus. Hal ini diperkuat dengan nilai sensitivitas dan spesifisitas yang menunjukkan nilai $96.55 \%$ dan $84.21 \%$. Hasil dari perbandingan ketiga ukuran tersebut menunjukkan bahwa classifier dapat mengklasifikasi dengan baik, namun classifier lebih mampu memprediksi mahasiswa untuk lulus lebih baik daripada mahasiswa yang tidak lulus. Hal ini terbukti ketika nilai sensitivitas lebih tinggi dari spesifisitas.

Untuk mengetahui keefektifan metode usulan ini, maka prediksi kelulusan menggunakan hybrid FIS dan DT akan dibandingkan dengan prediksi menggunakan hybrid FIS tanpa DT. Dengan demikian prediksi FIS dilakukan berdasarkan rule yang dibangkitkan oleh pakar berdasarkan experiment dan knowledge yang dimiliki oleh pakar. Rule yang digunakan adalah sebagai berikut:

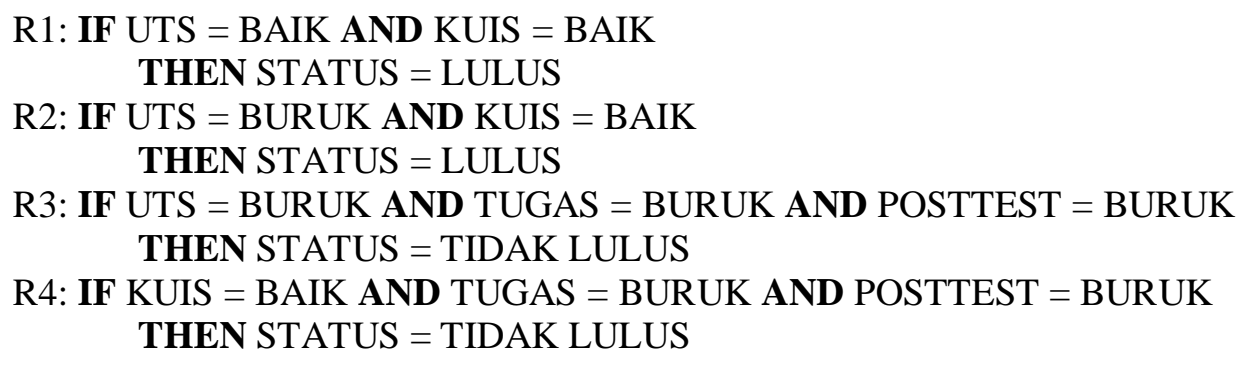

Dengan menggunakan kurva keanggotaan untuk fitur dan kurva keanggotaan label yang sama dengan sebelumnya (Gambar 4 dan Gambar 5) dan rule yang dibangkitkan oleh pakar, diperoleh hasil prediksi yang ditampilkan pada Tabel 3.

Tabel 3 Hasil Prediksi Kelulusan menggunakan FIS dengan rule yang Dibangkitkan oleh Pakar

\begin{tabular}{lccc}
\hline & \multicolumn{2}{c}{ Hasil Prediksi } & \multirow{2}{*}{ Jumlah } \\
\cline { 2 - 3 } & Lulus & Tidak Lulus & \\
\hline Lulus & 66 & 13 & 79 \\
Tidak Lulus & 21 & 6 & 27 \\
\hline Jumlah & 87 & 19 & 106 \\
\hline
\end{tabular}

Dari hasil klasifikasi tersebut dihitung pula akurasi, sensitivitas, dan spesifitas untuk membandingkan kesuksesan classifier yang diusulkan. Perbandingan hasil klasifikasi dapat dilihat pada Tabel 4.

Tabel 4 Hasil Perbandingan Prediksi

\begin{tabular}{lcc}
\hline & $\begin{array}{c}\text { Hybrid } \text { FIS dan DT } \\
(\%)\end{array}$ & $\begin{array}{c}\text { FIS } \\
(\%)\end{array}$ \\
\hline Akurasi & 94.33 & 67.92 \\
Sensitifitas & 96.55 & 83.54 \\
Spesifisitas & 84.21 & 22.22 \\
\hline
\end{tabular}

\section{Kesimpulan}

Penelitian ini memanfaatkan Educational Data Mining (EDM) untuk menentukan prediksi hasil belajar dalam tengah semester. Metode klasifikasi yang digunakan adalah hybrid Fuzzy Inference System (FIS) dengan Decision Tree (DT). DT digunakan untuk membangkitkan rule inferensi dalam fuzzy. Dalam pembangkitan rule, percabangan nilai dimulai dari nilai UTS yang artinya nilai ini adalah nilai yang paling signifikan berpengaruh dalam kelulusan. Selanjutnya dari DT yang terbentuk dapat dibangkitkan 5 rule yang kemudian dijalankan dalam FIS. Evaluasi classifier dihitung menggunakan ukuran akurasi, sensitivitas, dan spesifisitas. Dari tiga ukuran tersebut diperoleh akurasi sebesar 94.33\%, sensitifitas $96.55 \%$ dan spesifisitas $84.21 \%$. Nilai hasil evaluasi yang diperoleh menunjukkan bahwa rule yang dibangkitkan menggunakan DT dapat digunakan untuk rule classifier FIS dengan sangat baik. Hal ini dibuktikan dengan nilai akurasi, sensitivitas, dan spesifitas yang lebih tinggi daripada prediksi hanya dengan FIS. Namun dalam penentuan mahasiswa yang lulus sistem seringkali memprediksi mahasiswa tersebut tidak lulus. Lebih lanjut, penelitian ini masih sebatas prediksi yang hanya memperhitungkan nilai akademik saja, belum memperhatikan adanya nilai keaktifan dan nilai diskusi.

66 | Register: Jurnal Ilmiah Teknologi Sistem Informasi, Juli 2016, Volume 2, Nomor 2 
Oleh karena itu sangat memungkinkan penelitian ini dapat dikembangkan dengan memperhitungkan kemampuan komunikasi dan kelompok.

\section{Referensi}

Fawcett, T. (2006). An introduction to ROC analysis. Pattern Recognition Letters, 27(8), 861-874.

Gorunescu, F. (2011). Data Mining: Concepts, Models and Techniques. Berlin: Springer.

Jang, J. S., Sun, C. T., dan Mizutani, E. (1997). Neuro-Fuzzy and Soft Computing : A Computational Approach to Learning and Machine Intelligence. New Jersey: Prentice Hall.

Khan, I. A., dan Choi, J. T. (2014). An Application of Educational Data Mining (EDM) Technique for Scholarship Prediction. International Journal of Software Engineering and Its Applications, 8(12), 31-42.

Lindawati. (2008). Data Mining Dengan Teknik Clustering Dalam Pengklasifikasian Data Mahasiswa Studi Kasus Prediksi Lama Studi Mahasiswa Universitas Bina Nusantara. Seminar Nasional Informatika 2008 (semnasIF 2008) (hal. 174-180). Yogyakarta: UPN "Veteran" Yogyakarta.

Mentari, M., Sari, Y. A., dan Dewi, R. K. (2016). Deteksi Kanker Kulit Melanoma dengan Linear Discriminant Analysis-Fuzzy k-Nearest Neigbhour Lp-Norm. Register: Jurnal Ilmiah Teknologi Sistem Informasi, 2(1), 34-39.

Mutrofin, S., Izzah, A., Kurniawardhani, A., dan Masrur, M. (2014). Optimasi Teknik Klasifikasi Modified K Nearest Neighbor Menggunakan Algoritma Genetika. Gamma: Jurnal Penelitian Eksakta, 10(1), 130-134.

Swanjaya, D., dan Izzah, A. (2015). Educational Data Mining Untuk Mengetahui Pola Minat Kerja Mahasiswa. Seminar Teknologi dan Rekayasa (SENTRA). 1, hal. 1-6. Malang: Universitas Muhammadiyah Malang.

Urbanowicz, R. J., dan Moore, J. H. (2009). Review Article Learning Classifier Systems: A Complete Introduction, Review, and Roadmap. Journal of Artificial Evolution and Applications, 2009, 1-25.

Virgiawan, D. M., dan Mukhlash, I. (2013). Aplikasi Association Rule Mining Untuk menemukan Pola Pada Data Nilai Mahasiswa Matematika ITS. Jurnal Sains Dan Seni POMITS, 1(1), 1-6.

Witten, I. H., Frank, E., dan Hall, M. A. (2011). Data Mining: Practical Machine Learning Tools and Techniques (Third Edition ed.). Burlington: Morgan Kaufmann.

Yadav, S. K., dan Pal, S. (2012). Data Mining: A Prediction for Performance Improvement of Engineering Students using Classification. World of Computer Science and Information Technology Journal (WCSIT), 2(2), 51-56. 